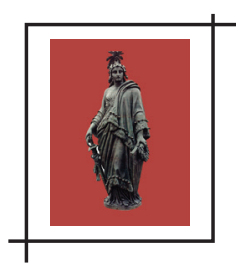

\title{
O LIVRE-ARBÍTRIO DA VONTADE EM AGOSTINHO DE HIPONA: 0 DILEMA DA VONTADE LIVRE E A RESPONSABILIDADE MORAL DO SER HUMANO
}

\author{
Ivan de Oliveira Silva ${ }^{1}$
}

Resumo: 0 presente trabalho tem por alvo analisar a doutrina de Agostinho de Hipona relativamente ao tema do livre-arbitrio da vontade, uma problemática que muito foi discutida pelo referido autor, especificamente em suas obras apologéticas e polemistas. 0 problema do mal tornou-se uma constante inquietação na vida de Agostinho e o fez um filósofo voraz ao procurar demonstrar que a vontade encontra um papel preponderante para a compreensão do conceito de livre-arbítrio, evidenciando, assim, que este é um elemento intrínseco à vontade. Sendo o livre-arbítrio da vontade a causa pela qual o homem pratica o mal moral, reservamos espaço para discutir as responsabilidades tanto do homem quanto de Deus pela má utilização dessa faculdade humana. Pretende-se, assim, evidenciar como o autor busca isentar Deus da acusação de ser o autor do mal, mostrando que a causa da presença do mal no mundo deriva do abuso do livre-arbítrio, visto que, considerado em si mesmo, este atributo da vontade é um bem e um dom do Criador concedido ao próprio homem.

Palavras-chave: Liberdade. Vontade. Mal. Moral. Deus.

\section{INTRODUÇÃO}

0 estudo da obra de Agostinho é sempre um desafio, sobretudo pelo fato de que ao tempo em que o Bispo de Hipona se mostra como um filósofo voraz, com uma estrutura de raciocínio de gigantescas proporções, há nele também um confesso defensor da fé cristã. É o seu lado teólogo que não deixa de aflorar em sua obra. Assim, fé e razão entrecruzam-se nos textos de Agostinho, sendo difícil dizer quando inicia uma e começa outra. Mas é este tempero que faz do pensamento de Agostinho sempre instigante.

Diante dessas considerações preliminares, o presente trabalho tem por alvo analisar a doutrina de Agostinho de Hipona relativamente ao tema do livre-arbítrio da vontade, grave problema que muito foi discutido pelo autor, notadamente em suas obras apologéticas e polemistas.

1 - Doutor em Direito do Consumidor pela Universidade Metropolitana de Santos/SP. Mestre em Direitos Difusos e Coletivos pela Universidade Metropolitana de Santos/SP. Mestre em Ciências da Religião pela Universidade Presbiteriana Mackenzie. E-mail: ivanoliveira.prof@hotmail.com 
A abordagem deste artigo procura demonstrar que a vontade encontra um papel fundamental para a compreensão do livre-arbítrio no pensamento de Agostinho. Evidencia-se, assim, que o livre-arbítrio é um elemento intrínseco à vontade. Razão pela qual, o texto atribui ênfase à fórmula agostiniana livre-arbitrio da vontade, presente nos escritos originais do Hiponense.

Sendo o livre-arbitrio da vontade a causa pela qual o homem pratica o mal moral, reservamos espaço para discutir as responsabilidades tanto do homem quanto de Deus pela má utilização dessa faculdade humana. Sendo certo que, em tais discussões complexas, Agostinho dedicou grande parte de seus escritos para atacar as doutrinas dos maniqueus, grupo do qual ele fez parte por quase nove anos.

Com vistas a alimentar a discussão dos temas aqui propostos, o texto não deixa de lado abordagens acerca da fonte e da natureza do livre-arbítrio da vontade, bem como o papel da justiça divina diante da sua má utilização. Analisa-se, ainda, a relação do livre-arbítrio e a origem do mal moral, representado pelo ato humano de distanciamento do bem.

Por fim, diante de uma premissa muito cara a Agostinho, que segue no sentido de que a pessoa humana não tem forças para se levantar sozinha de sua condição decaída, passamos a discutir o papel da graça divina no plano de resgate do indivíduo que se encontra em constantes conflitos existenciais decorrentes do seu estado de queda.

Eis, a título de introdução, o plano deste artigo que abordou o palpitante tema do livre-arbitrio da vontade no pensamento de Agostinho de Hipona.

\section{VONTADE LIVRE: PONTO DE PARTIDA PARA A COMPREENSÃO DO LIVRE-ARBÍTRIO DA VONTADE}

Liberum voluntatis arbitrium. Esta é a maneira recorrente pela qual Agostinho de Hipona prefere identificar as ações humanas originárias de atos voluntários. Assim, quando o hiponense demonstra a sua preferência pela fórmula livre-arbitrio da vontade, ao invés de tão somente livre-arbitrio, tem-se a impressão de que o livre-arbitrio pertence à vontade. Consoante esta constatação, relevante a abordagem do sentido do termo vontade e a sua relação com o livre-arbitrio.

$\mathrm{Na}$ fórmula agostiniana livre-arbitrio da vontade vê-se que é a vontade que exerce o livre-arbítrio, podendo dele utilizar-se conforme a ordem preestabelecida pelo Criador, vale dizer, do Bem imutável. A partir disso, não há de se falar em livre-arbitrio sem vontade ou, ainda, em vontade sem livre-arbitrio, visto que em ambas as hipóteses haverá uma vontade teratológica, inserida em uma condição de absoluta inércia. Neste sentido, o livre-arbítrio é um elemento da vontade, sendo que esta faz as suas escolhas por meio daquele.

Para Agostinho o homem, ser racional por excelência, é dotado da vontade livre capaz de fazer escolhas livres e responsáveis. Dessa maneira, a vontade livre, utilizando-se do livre-ar- 
bitrio, tem a opção de escolher afastar-se ou aproximar-se do bem, respondendo o homem tanto em um quanto noutro caso, visto que o ser humano, para Agostinho, é uma criatura eminentemente moral. E, portanto, responsável pelos seus atos, sejam eles moralmente considerados bens ou maus.

Quando o homem age conforme um conjunto de valores definidos pelos postulados da fé cristã ocidental, entende Agostinho que assim o faz em decorrência da boa vontade. Por outro lado, seguindo tradição de seu tempo, a doutrina agostiniana segue no sentido de que a vontade, embora boa por natureza, está corrompida em decorrência do pecado original, sendo que este conduz o homem ao caminho das más escolhas, ou seja, para um encadeamento de opções humanas que promovem o afastamento da criatura do Bem Imutável.

Para Agostinho, a criatura cumpre sua razão de existência somente quando se aproxima do Bem imutável e universal, ou seja, o Criador (AGOSTINHO, 1995, p. 141-142). Nesse contexto, o homem virtuoso deve empreender esforços da sua existência, boa por natureza, na escolha do bem e, assim, forçar a sua natureza decaída ao afastamento do mal, o que ocorrerá por meio da escolha adequada da vontade livre.

A vontade livre, segundo Agostinho, acena para uma responsabilidade absoluta do homem. A vontade, e o seu correspondente livre-arbitrio, ganha um papel de grande relevância nas ações humanas já que "contra a vontade, ninguém procede bem, ainda que a ação em si mesma seja boa" (AGOSTINHO, 1973, p. 35). Portanto, em todas as instâncias é o homem responsável pelos seus atos, sejam bons ou maus.

Agostinho mudou de posição algumas vezes em sua trajetória intelectual. Em seus primeiros escritos, chegou a entender que o homem está no controle de sua vida e de suas escolhas morais, afastando qualquer determinismo. Ao interpretar esta fase agostiniana, Mariana Palozzi Sérvulo da Cunha sugere que Agostinho sustentava que "a vontade pertence ao homem, está em nosso poder querer ou não querer algo. Sendo por meio dela que se comete o mal, este é atribuído ao próprio homem. (...) quando queremos algo queremos com vontade, se não fosse assim, não quereriamos de fato" (CUNHA, 2001, p. 76).

A vontade livre é um instrumento para o homem alcançar a sabedoria. Contudo, o movimento em direção à sabedoria somente ocorrerá em decorrência da boa vontade, visto que a má vontade representa exatamente o afastamento da sabedoria. Assim, a boa vontade "é a vontade pela qual desejamos viver com retidão e honestidade, para atingirmos o cume da sabedoria" (AGOSTINHO, 1995, p. 56). Sendo relevante destacar que o ápice da sabedoria é representado pela proximidade do ser criado, o homem, com o Criador, Deus.

A vontade livre ocupa um lugar de extrema importância no pensamento de Agostinho, tanto é que o referido pensador chega, em dado momento, a identificá-la com o amor ou a dileção e afirma que, quando isto ocorre, tem-se a vontade com maior vigor (AGOSTINHO, 2002, p. 41), que de maneira vigorante poderá seguir tanto rumo a sabedoria ou para o seu 
contrário. Nesse sentido, afirma o hiponense: "dois amores fundaram, pois, duas cidades, a saber: o amor próprio, levado ao desprezo a Deus, a terrena; o amor a Deus, levado ao desprezo de si próprio, a celestial" (AGOSTINHO, 2003, p. 28).

No rumo da afirmação supra, pode-se dizer que duas vontades criaram duas cidades, sendo que a má vontade criou a cidade terrena, que tem como norte o distanciamento do Sumo Bem; e, em outro sentido, a boa vontade, por sua vez, criou a cidade celeste, que tem como alvo a busca do Sumo Bem.

\section{BELIGERÂNCIA DAS VONTADES}

Embora o homem seja dotado de vontade livre, há nele a boa vontade e a má vontade, cada uma com intenções próprias no momento em que se operam as escolhas humanas. Diante desta dualidade, Agostinho sugere que há, em cada ser humano, um constante atrito entre a boa e a má vontade. Nesta perspectiva, declara o mestre de Hipona que dentro dele havia uma verdadeira guerra entre essas vontades (AGOSTINHO, 1973, p. 162).

A partir da noção de guerra entre as vontades, a partir de sua experiência particular, sugere Agostinho a existência de um constante conflito interior suportado pela pessoa humana. A esse respeito, declara: "assim, duas vontades, uma concupiscente, outra dominada, uma carnal e outra espiritual, batalhavam mutuamente em mim. Discordando, dilaceravam-me a alma" (AGOSTINHO, 1973, p. 157).

Como se verifica, a existência humana terrena está marcada por uma inflexível luta das vontades. Diante desse dilema, Evans interpreta que "o caminho agostiniano para a perfeição está, pois, cheio de ciladas, e é caminho tão longo que ele pergunta se alguém chega ao fim dele nesta vida" (EVANS, 1995, p. 237). Em função disso, "devemos lutar pelo resta de nossa vida com a vontade para o mal que permanece em nós depois do batismo. 0 fato de que a vontade má permaneça em nós não é em si importante. Não é preciso sentir-se culpado enquanto a ela não cedermos" (EVANS, 1995, p. 237).

Para Agostinho, pensador cristão do período medievo, a vida cotidiana não passava de uma sombra da vida futura, oportunidade em que haverá galardões para aqueles que direcionarem a vontade livre para as escolhas excelentes. No afã de demonstrar que o homem, nesta vida terrena, deve resistir aos apelos da vontade corrompida e optar pelos bens incorruptíveis, em uma conotação extremamente pia, assevera Agostinho, em uma de suas obras pastorais, que esta vida é moribunda e os deleites aqui vivenciados não passam de incertezas diante da felicidade no porvir (AGOSTINHO, 2000a, p. 190).

No cristianismo de vertente agostiniana, o norte para o homem direcionar o seu livre-arbítrio, conforme os ditames de uma ordem preestabelecida pelo bem imutável, é a atenção à promessa de uma excelente e duradoura felicidade no porvir. Assim, para Agostinho, a opção 
da vontade livre é racional. No entanto, a espera do cumprimento da promessa de gozo dos bens no além-vida tem sua base em postulados de fé.

Contudo, não se deve entender que a vontade livre, no plano terreno, seja uma fonte inesgotável de sofrimento e, por conseguinte, tenha uma natureza má e nefasta que funcione como uma terrivel chaga capaz de colocar o livre-arbitrio em estado de putrefação em detrimento do homem. Contrariamente, sustenta Agostinho que a vontade livre não é má em si mesma, eis que ela pode fazer os homens aproximarem-se do Sumo Bem e possibilitar ao homem o gozo da perene felicidade, pois a vontade livre, mesmo sujeita a corrupção, deve ser compreendida como um bem por natureza (AGOSTINHO, 1995, p. 91-96).

A vontade livre exerce um importante papel para o alcance da felicidade humana. De modo que, segundo Agostinho, "depende de nossa vontade gozarmos ou sermos privados de tão grande e verdadeiro bem" (AGOSTINHO, 1995, p. 56-57). Assim, a vontade é um bem para o homem alcançar a felicidade, mas não é incomum a noção de dilema entre as vontades. Étienne Gilson (2007, p. 253), a propósito, aponta que "não é, pois, exagerado dizer que assim como é a vontade, tal é o homem, a tal ponto que uma vontade partida contra si mesma é um homem dividido contra si mesmo".

Contudo, mesmo diante dos dilemas morais decorrentes do atrito entre a boa vontade e a má vontade, Agostinho não abre mão da noção de responsabilidade humana pelas escolhas realizadas pelo homem. Esse é um ponto presente em todas as fases do pensamento agostiniano e, por conseguinte, para o Bispo de Hipona, o homem é o responsável moral pelo movimento do seu livre-arbítrio da vontade.

\section{AGOSTINHO VERSUS MANIQUEUS: A QUESTÃO DA VONTADE CORRUPTIVEL E DA UNIDADE DA ALMA A PARTIR DE UM PRINCÍPIO INCORRUPTÍVEL}

Agostinho não poupa críticas ao maniqueísmo. E, em relação a ele, chega a dizer que foi seduzido por homens orgulhosamente extravagantes, carnais e loquazes que tão somente o afastaram da verdade e o fizeram ouvir, segundo seu julgamento posterior, ficções brilhantes $^{2}$. 0 seu confronto com o maniqueísmo muito contribuiu para a formulação e amadurecimento de suas doutrinas, pois ao mesmo tempo que ele se ocupava com o ataque às ideias maniqueias teve a oportunidade de estruturar as suas próprias.

\footnotetext{
2 - Agostinho, com o corriqueiro tom de pesar e repúdio pelos maniqueus, anota que "havia na sua boca laços do demônio e um engodo, preparado com mistura de sílabas do vosso nome, de Nosso Senhor Jesus Cristo e do Paráclito consolador, o Espirito Santo. Jamais esses nomes se Ihes retiravam dos lábios, mas eram apenas sons e estrépito da língua. 0 seu coração está vazio de sinceridade. Diziam: 'Verdade e mais verdade!'. Incessantemente me falavam dela, mas não existia neles" (AGOSTINHO, 1973, p. 61).
} 
Dificil imaginarmos a complexidade da obra de Agostinho sem o tempero destinado a refutar os maniqueus ${ }^{3}$. Infelizmente, a maioria dos escritos maniqueístas que chegaram à contemporaneidade não passam de fontes secundárias de autoria de comentaristas que, amiúde, se ocuparam mais em criticá-los do que propriamente sistematizar as doutrinas maniqueias. 0 próprio Agostinho, que durante nove anos esteve entre os maniqueus, mostrou-se um de seus críticos mais vorazes e não teve nenhum interesse em apresentar imparcialmente o maniqueísmo de seu tempo. Ao contrário, esforçou-se apenas em reproduzir fragmentos dos textos maniqueus com o propósito veemente de refutá-los. Contudo, o conjunto de fragmentos ainda é extremamente relevante para a compreensão de tal sistema, pois se não fossem os seus opositores, com destaque para Agostinho, fatalmente quase nada teríamos. $^{4}$

Não obstante a dificuldade de localização de fontes primárias dos maniqueus que possibilitem uma construção imparcial de suas doutrinas, apurou-se que a estrutura doutrinária dos maniqueístas sustenta a existência de dois princípios ontológicos que, em igualdade de potências, encontram-se constantemente em manifesta oposição. Estes princípios são designados como o do bem e o do mal.

0 maniqueísmo, embora titular de uma estrutura de pensamento filosófica, pode ser compreendido também como uma religião de mistério. Desse modo, há na doutrina maniqueia um conjunto complexo de ideias que perpassam desde uma curiosa compreensão da criação até uma escatologia soteriológica em que o homem aparece como refém da matéria, que é eminentemente má. Contudo, diferentemente do que corriqueiramente se postula no ideário da cultura ocidental, sustentavam os maniqueístas que não há qualquer superioridade entre o bem e o mal, respectivamente, luz e trevas. Assim as trevas e a luz, ou o mal e o bem, estão em condições de igualdade de forças nesta batalha originada em tempos imemoriais. ${ }^{5}$

Pondera Justo L. González que, na doutrina dos maniqueus, dado o dualismo radical entre o bem e o mal, "particularmente no ser humano estes dois princípios estão interligados e, portanto, numa luta contínua" (2005, p. 446). Sobretudo, na luta entre a alma e o corpo do homem. Para o maniqueísmo dos primeiros séculos da era cristã, o mal, presente na matéria,

\footnotetext{
3 - A oposição de Agostinho com os maniqueístas, não se resume somente na questão do mal, vai mais além. A título de exemplo, basta citar a sua refutação feita quanto ao tema dos casamentos bígamos celebrados pelos patriarcas do Antigo Testamento. Nesta querela, Agostinho afirma, diferentemente dos maniqueus, que os patriarcas celebravam casamentos bígamos por conta da necessidade de procriação e não por sensualidade. (AGOSTINHO, 2000a, p. 67).

4 - Afirma, com razão, Marcos Roberto Nunes Costa que "a documentação indireta, escrita pelos chamados heresiólogos, embora não traga os textos originais na integra, mas apenas fragmentos ou interpretações destes, muitas vezes preconceituosas ou distorcidas, foram as primeiras que chegaram até nós, e são de fundamental importância para a compreensão do maniqueismo..." (COSTA, 2003, pp. 17-18).

5 - No tratado Del génesis contra los maniqueus (De Genisi Contra Manichaeos), Agostinho (1957) esforça-se em repudiar os postulados maniqueistas da criação do cosmos e da humanidade.
} 
é concebido como um princípio em constante oposição ao bem. Sendo este uma partícula coeterna com o mal. Ocorre que nesta perspectiva de forças coeternas, dotadas de igual potência, há um embate eterno, embora os maniqueistas atribuam melhor valor ao bem. ${ }^{6}$

Entendiam os maniqueus que o corpo humano reproduzia a substância do mal. Neste sentido, o nascimento de uma pessoa implicava mais partículas do bem aprisionadas na matéria má, vale dizer: o corpo. Esta é a pessimista antropologia maniqueista, vez que o corpo humano é uma impiedosa prisão das partículas do bem. Neste particular, os maniqueistas aproximavam-se de Plotino que, embora entendesse que o mal era o não-ser, sustentava paradoxalmente que a matéria era o mal absoluto que representava uma prisão da alma ${ }^{7}$, sendo que da matéria "provém a divisão, a discórdia, porque a matéria é o absoluto mal e não-ser, degrau último de todas as coisas, limite final da descida" (SANTOS, [19--], p. 156).

De igual modo, tem-se a influência de Plotino em Agostinho na compreensão de que o mal deve ser visto como o não ser. Entretanto, o hiponense rejeita o postulado plotiniano de que a matéria seja o mal absoluto, pois para Agostinho a matéria foi originada de um ato da criação e, por conta disso, deve ser considerada como um bem por natureza, na medida em que o Criador, ao analisar a sua obra, afirmou que toda ela era boa. Para Agostinho ir em sentido contrário seria um sacrilégio à fé que ele defendia.

Especificamente quanto ao dualismo maniqueu, Agostinho rejeitou a existência de duas substâncias coeternas e de iguais potências em constante confronto no Universo. Ao contrário disso, sustentou a existência tão somente de uma substância, a do bem, negando, por conseguinte, a existência ontológica do mal. Neste diapasão, o mal é compreendido como o não-ser, eis que toda substância é o ser, ou seja, o bem. Assim, as coisas "enquanto existem, são boas. Portanto, todas as coisas que existem são boas, e aquele mal que eu procurava não é uma substância, pois, se fosse substância, seria um bem" (AGOSTINHO, 1973, p. 140). Com isso, ontologicamente, sugere-se que toda a criação é boa, e o que não é bom simplesmente não existe e deve ser compreendido como um erro de alvo, um afastamento do bem.

Afirma Agostinho: "procurei o que era a maldade e não encontrei uma substância, mas sim uma perversão da vontade desviada da substância suprema (...)" (AGOSTINHO, 1973, p. 142). Portanto, o mal não tem substância e o ato de afastar-se do bem surge em decorrência da vontade corrompida que, voluntariamente, opta pela tentativa de subversão da

\footnotetext{
6 - Observemos, a propósito, as afirmações de Nunes Costa: "quanto ao poder e valor desses dois reinos, duas considerações merecem destaque: primeiro, quanto ao poder, por terem princípios idênticos e independentes, cada um tem idêntica potência. Assim, por exemplo, ambos têm poder de criar, ou melhor, de emanar, e na luta cósmica medem forças em pé de igualdade. Em relação ao valor, os maniqueus afirmam que a Luz [o bem] é superior às Trevas [o mal], por suas qualidades intrínsecas de bondade, beleza e inteligência" (COSTA, 2003, p. 49).

7 - Ao estudar o pensamento de Plotino, afirmou, com acerto, Carlo Bússola, que para o referido pensador neoplatônico "o corpo, assim, é a prisão da alma. Com efeito, a alma tem aspirações diferentes e superiores às do corpo. Fundamentalmente, a alma aspira juntar-se de novo à Alma Universal da qual se desprendeu" (BUSSOLA, 1990, p. 32).
} 
ordem estabelecida na criação. Ou seja, todas as coisas foram criadas boas por natureza e têm elas uma ordem própria preestabelecida pelo Criador, o Sumo Bem. 0 ato de afastar-se do bem, por conseguinte, denota uma corrupção da ordem e, assim, sugere uma corrupção da criatura.

Ainda que Agostinho considere a existência de uma vontade corrompida, não entende ele que a vontade livre seja um mal, dado o fato de inexistência de uma substância ontológica de um princípio da maldade. Quando se considera que a vontade existe e tem substância, a partir da doutrina cristã agostiniana, há de se entender que a sua existência deriva do ato criador. Assim, a vontade de um princípio bom e incorruptivel, vale dizer, do Sumo Bem.

Embora a vontade seja corruptível, em decorrência da queda presente na narrativa cristã, é ela derivada do Bem incorruptivel e universal, motivo pelo qual ela é um bem por natureza.

A vontade humana não tem a mesma natureza do Sumo Bem, caso contrário seria ela incorruptível e, em consequência, o homem seria dotado de uma vontade idêntica a da divindade. No instante da criação, Deus não transmitiu a sua natureza às criaturas, por que se assim o fosse todos os homens seriam idênticos a Ele e, desse modo, a criatura também seria Deus. Esta hipótese está completamente fora de cogitação na ortodoxia cristã defendida por Agostinho. Quando Agostinho descreve a luta das vontades, uma boa e outra má, não quer ele dizer que há dois princípios coeternos no ser humano. Isso era defendido pelos maniqueus. A vontade, dita má, corresponde a tendência derivada do pecado original em afastar-se do bem, ou seja, em corromper a ordem estabelecida dos bens criados. Não há, portanto, de se falar em substância de maldade na vontade humana, visto que esta foi criada por Deus e concedida ao homem como um bem. Neste sentido, em uma prece dirigida a Deus, afirma Agostinho (1973, p. 140) que

[...] o mal não existe nem para Vós, nem para as vossas criaturas, pois nenhuma coisa há fora de Vós que se revolte ou que desmanche a ordem que Ihe estabelecestes. Mas porque, em algumas das suas partes, certos elementos não se harmonizam com outros, são considerados maus. Mas estes coadunam-se com outros, e por isso são bons (no conjunto) e bons em si mesmos.

Quando Agostinho utiliza-se da expressão má vontade não está querendo dizer que haja uma substância ontológica do mal na vontade humana, visto que isto desmoronaria a sua tese de não substância do mal concebida em refutação ao maniqueísmo de seu tempo.

No pensamento agostiniano, o Sumo Bem criou todas as coisas boas, sendo que este princípio de bondade e de poder, não se encontra, de maneira alguma, desafiado pelo mal. Pensar em sentido contrário, como faziam os maniqueus, coloca em questionamento um dogma muito caro a Agostinho, e ao cristianismo, que é o da soberania de Deus. A ideia de um Deus soberano afasta a tese maniqueia de um princípio mal prestes a destronar o Sumo 
Bem ou medindo forças de igual potência e limitando os seus movimentos. Decididamente esta não é a visão que Agostinho tem de um Criador como Bem incorruptivel e universal.

\section{A ALMA E AS VONTADES EM ATRITO: A VERSÃO AGOSTINIANA DO DILEMA HUMANO}

Destacou-se nos itens acima, a luta das vontades dentro de um cenário psicológico, ou seja, nos limites do ser agostiniano. Neste momento, analisaremos a luta entre a alma e as vontades de uma perspectiva de aversão às doutrinas maniqueias e com o registro de uma dubiedade tanto de uma quanto da outra no domínio total da alma. É a discussão que se segue.

Nas considerações sobre a alma, Agostinho apresenta um ponto de partida extremamente rígido que não admite variantes, qual seja: "a alma foi criada por Deus e tem natureza própria porque assim the foi concedida pelo mesmo que criou a alma e criou os quatro elementos, ou seja, por Deus" (AGOSTINHO, 1997, p. 23). 0 mestre de Hipona não abre mão da premissa de que Deus criou todas as coisas e que elas foram feitas boas, embora corruptíveis porque se assim não fossem, elas teriam os mesmos atributos divinos, hipótese rejeitada na obra agostiniana.

A centralidade do pensamento agostiniano é que um Ser perfeito e incorruptível somente poderá conceber uma obra de natureza boa e aprazivel para si próprio. Por conta disso, a alma foi criada e é dotada de natureza própria, sendo ela o centro da identidade humana.

0 homem (criatura boa por natureza e de substância oriunda da vontade do Sumo Bem, embora não da mesma substância incorruptivel) é dotado de vontade livre que, em decorrência da queda, encontra-se em um constante conflito diante das escolhas entre os bens que Ihe estão disponiveis. Quanto mais excelente seja o bem, mais próxima da condição de exercício da boa vontade.

Contudo, o grande dilema humano consiste na opção da melhor escolha da vontade. Para Agostinho o homem sempre deve escolher, de modo que viver significa estar inserido em um variado conjunto de opções de escolhas, sendo certo que o caráter humano se reconhece pelas escolhas realizadas. 0 conflito das vontades é compreendido por Agostinho como doença da alma que se apresenta como um querer e um não querer. Nesse rumo, argumenta Agostinho: "portanto, não é prodígio nenhum em parte querer e em parte não querer, mas doença da alma. Com efeito, esta, sobrecarregada pelo hábito, não se levante totalmente, apesar de socorrida pela verdade. São, pois, duas vontades. Porque uma delas não é completa, encerra o que falta à outra" (AGOSTINHO, 1973, p. 162).

0 dilema do querer e do não querer fez com que os maniqueus sustentassem que 0 homem era portador de duas almas, uma boa e outra má, causadoras do conflito das vontades (AGOSTINHO, 1973, p. 164). Essa formulação foi repelida por Agostinho. Diante disso, ele 
coloca a alma como centro da identidade humana, ou seja, como o próprio eu, sua própria existência. Observe-se, a respeito, a afirmação do hiponense: "quando eu deliberava servir já o Senhor meu Deus, como há muito tempo tinha proposto, era eu o que queria e era eu o que não queria; era eu mesmo" (AGOSTINHO, 1973, p. 164).

Agostinho aceita que há um conflito interno no homem em decorrência de lutas das vontades, mas repele a doutrina maniqueia de multiplicidade de almas. Temos, assim, duas vontades em beligerância, mas apenas uma alma. 0 homem tem somente uma alma, que se encontra diante de duas vontades em atrito, a boa vontade e a má vontade. Isso não implica dizer que haja, nas vontades, duas naturezas. Ou seja, não há uma substância ontológica do mal na vontade 8 .

A rejeição da existência de uma natureza ontológica do mal é rejeitada em vários momentos da obra agostiniana. A título de exemplo, considere-se a seguinte afirmação: "toda e qualquer natureza enquanto natureza é sempre um bem - não pode provir senão do supremo e verdadeiro Deus, porque o ser de todos os bens, tanto os que pela sua excelência se aproxima do Sumo Bem como os que pela sua simplicidade se afastam d'Ele, não pode provir senão do Sumo Bem" (AGOSTINHO, 2005, p. 5).

\section{FONTE E NATUREZA DO LIVRE-ARBÍTRIO DA VONTADE}

Agostinho entende que as Escrituras contêm a revelação de que o homem possui o livre-arbítrio da vontade para bem viver retamente (AGOSTINHO, 1956a), sendo que o pecado do primeiro homem, Adão, foi exatamente o mau uso deste livre-arbitrio concedido pelo Sumo Bem (AGOSTINHO, 1995, p. 75-76). Entretanto, o livre-arbitrio da vontade é um bem concedido ao homem por Deus e, portanto, a sua natureza é boa, já que do Sumo Bem somente procede obras boas e justas (AGOSTINHO, 1995, p. 134-135).

Não é por que o homem, por vezes, utiliza de maneira inadequada o seu livre-arbítrio da vontade que ele se transmudará em um mal, visto que é ele um bem por natureza e, portanto, nunca se transformará em um mal, eis que no conjunto ainda será um bem. Assim, no pensamento agostiniano, o livre-arbítrio tem fonte divina, procedente do Sumo Bem. Sendo obra da criação divina, somente pode ser compreendido como um bem, por natureza.

Para Agostinho nenhuma natureza é má enquanto natureza (AGOSTINHO, 2005, p. 17). Contudo, é possivel que ela se corrompa e é exatamente esta corrupção da natureza que é considerada um mal, mas não a coisa em si. Logo, tem-se que o mal é o um desvio da ordem

8 - Embora Agostinho (1985) tenha recebido esta acusação de Juliano, tratou de rechaçá-la ferozmente. É o que se observa na obra apologética intitulada Réplica a Juliano. 
estabelecida por Deus. Entretanto, mesmo quando o homem, por meio do livre-arbítrio da vontade, escolhe o afastar-se do bem, há de se considerar que Deus continua no controle da criação e assim tudo continua na ordem preestabelecida (AGOSTINHO, 1956b, p. 675).

Nesse sentido, o homem, com a sua vontade dotada de livre-arbitrio, no conjunto de todas as coisas criadas por Deus, não tem forças para alterar o plano da criação. Mas é certo que há uma subversão da ordem quando o livre-arbítrio, de natureza boa, é utilizado contra a sua natureza. Como esse ato é voluntário, surge espaço para a paga do homem pelo seu comportamento avesso à ordem preestabelecida pelo Sumo Bem. Assunto este que será objeto de atenção no tópico seguinte.

\section{O LIVRE-ARBÍTRIO DA VONTADE E A JUSTIÇA DIVINA}

Concernente à tentativa de equilibrar a relação do livre-arbítrio da vontade com a vontade do Criador, surge uma questão interessante a ser enfrentada, qual seja: como pode um Deus incorruptível, dotado de presciência, conceder ao homem o livre-arbítrio da vontade capaz de permitir à criatura o afastamento do Bem imutável e universal? Agostinho procura enfrentar esta e outras questões a ela correlata. Observemos.

Para Agostinho de Hipona, Deus é considerado um Bem imutável e universal de onde procede todo o bem, sendo que a vontade livre (que tem a faculdade de escolha por meio do livre-arbítrio) é considerada um bem médio, haja vista que ela pode optar tanto pela aproximação como pelo distanciamento do bem. A partir disso, o hiponense rejeita a compreensão de que o livre-arbítrio da vontade seja um mal, na medida em que pode conduzir o homem às escolhas más.

Para rejeitar a compreensão de ser a vontade livre, dotada de livre-arbítrio, um mal e um equívoco da divindade, Agostinho vale-se do seu tratado denominado De Libero Arbitrio em que, após um conjunto de argumentos antimaniqueus, apresenta o livre-arbítrio da vontade como uma dádiva concedida por Deus aos homens. Estabelece a ideia de que o problema não é o livre-arbítrio, mas a maneira como ele é utilizado para promover o afastamento do bem.

Seguindo a doutrina agostiniana, podemos considerar o seguinte: imagine-se a contribuição benéfica dos olhos, dos pés e dos braços no cotidiano de uma pessoa. Não é por que determinados individuos utilizam-se de tais membros de maneira inapropriada, e até mesmo para o cometimento de delitos, que eles podem ser considerados maus por natureza. É o que ocorre com a vontade dotada de livre-arbitrio, na medida em que uns utilizam-na conforme apraz o Bem imutável e universal, sendo que outros individuos a utilizam para aborrecimento do Criador em manifesta inversão da ordem por Ele preestabelecida.

Exemplificando: não é por que alguém se utiliza de uma faca para matar um indefeso recém-nascido que seja possivel afirmar que a faca seja um malefício por natureza, já que 
este mesmo instrumento pode ser utilizado para a manipulação de alimentos e a manutenção da vida humana. Inclusive, de outros bebês.

Não é por que o homem tenha o poder de utilizar inadequadamente a vontade livre que ela deva ser considerada um mal. Ao contrário disso, sustenta Agostinho que, exatamente por este motivo, ela é considerada um bem médio, visto que permite ao homem, voluntariamente, escolher entre os bens inferiores quando deveria escolher adequadamente os bens superiores (AGOSTINHO, 1995, p. 140-142). 0 erro de escolha é sempre do homem e não de Deus que concedeu ao homem o livre-arbítrio da vontade. Se existir, portanto, um mal, este mal é de fundo moral, representado pela escolha indevida do homem que, por ato de vontade, inverte a ordem estabelecida previamente pelo Criador.

Por outro lado, a vontade livre, que é a vontade dotada de livre-arbítrio, é um bem capaz de manifestação da justiça divina, visto que cada homem receberá a adequada paga pelo seu ato livre. Desse modo, caso o homem pratique o mal moral (compreendido como a inversão da ordem preestabelecida em que o homem se aproxima dos bens inferiores em detrimento dos superiores) estará sujeito a correspondente punição pelo Criador.

Quando Agostinho sustenta que a punição pela prática do mal moral é justa por que este é responsável pelos seus atos voluntários, encontramos aqui a forte ideia cristã de castigo e bênção divinos que se operam segundo a justiça divina. A punição sob o império da justiça divina, segundo a compreensão agostiniana e cristã, emana do constante julgamento do Criador sobre as ações voluntárias da criatura racional e assim ocorre em decorrência da responsabilidade humana pelos atos praticados. Decorre, ainda, do fato de que toda a ação do homem está sujeita a julgamento.

Nessa perspectiva o livre-arbítrio da vontade está sob a constante vigilância Divina. Entretanto, não é por tal motivo que o homem está fora do controle de seus atos. Mas, em sentido inverso, o homem é compreendido como um ser moral, responsável pelos seus atos e é nesta condição que será julgado ${ }^{9}$.

Agostinho, como escritor cristão, identifica aqueles que invertem a ordem, por meio do livre-arbitrio da vontade, como pecadores e, neste sentido, afirma que os homens "que pelo pecado saírem da ordem, tornam à ordem mediante o castigo. Como esta ordem não corresponde à sua natureza, chamamo-la pena; mas, por ser o que cabe à culpa, dizemo-la justiça" (AGOSTINHO, 2005, p. 7). Evidencia-se que Agostinho identifica o castigo divino como um bem capaz de chamar o homem, dotado de livre-arbítrio da vontade, à ordem.

Entende Agostinho que o castigo divino é justo exatamente pelo fato de que o homem foi criado como um ser racional capaz de tomar suas decisões voluntariamente e, por conse-

9 - A influência do Apóstolo Paulo no pensamento de Agostinho é marcante, observe-se, a propósito, o conteúdo do versículo 7, do capítulo 6 da Carta aos Gálatas: "Não vos enganeis: de Deus não se zomba; pois aquilo que o homem semear, isso também ceifará" (G| 6.7). 
guinte, é moralmente responsável pelos seus atos. Por essa ótica, o livre-arbítrio da vontade faz parte do plano da justiça divina. 0 livre-arbítrio da vontade foi concedido ao homem para que este optasse pelo bem, sendo que a opção pelo desvio do bem é uma mostra de corrupção e, por conta disso, de má utilização do livre-arbitrio da vontade. É este, por conseguinte, o motivo da pena. ${ }^{10}$ "Visto que a conduta desse homem não seria pecado nem boa ação, caso não fosse voluntária. Igualmente o castigo, como a recompensa, seria injusto, se o homem não fosse dotado de vontade livre" (AGOSTINHO, 1995, p. 74).

Há de se sublinhar, diante do exposto, que o livre-arbitrio da vontade se mostra como adequado à aplicação da justiça de Deus pelos atos voluntários praticados pelo homem. Decorre disso que "as más ações são punidas pela justiça de Deus. Ora, elas não seriam punidas com justiça, se não tivesse sido praticada de modo voluntário" (AGOSTINHO, 1995, p. 25).

Considerando que ninguém está forçado a pecar, seja por sua própria natureza, seja pela natureza de outrem, logo só vem a pecar por sua própria vontade (AGOSTINHO, 1995, p. 133136), tem-se que o ser humano é moralmente responsável pelos seus atos e sujeito a receber a paga pelo seu comportamento contra a ordem divinamente estabelecida.

Da responsabilidade moral do homem Agostinho não abre mão. Vê-se, portanto, que o problema ganha proporções no nivel moral, razão pela qual, abordaremos esta temática no título seguinte.

\section{A ORIGEM DO MAL MORAL DECORRE DO LIVRE-ARBÍTRIO DA VONTADE}

Como vimos, Agostinho nega a existência do mal no Universo, negando-Ihe substância e, por conseguinte, considera o mal como um mero distanciamento do bem. Em sua doutrina, o mal é apresentado como o não-ser, sem princípio, sem meio e sem fim. Contudo, a solução agostiniana ao problema do mal no Universo criado, não afastou o problema do mal no homem. 0 mal moral é identificado como pecado e o homem é visto como uma criatura responsável pelos seus atos porque dotado de vontade livre.

0 mal moral afasta, de certa forma, uma suposta relação entre o mal e Deus e, em sentido contrário, centraliza a problemática do mal no homem, haja vista que a criatura é responsável pela má utilização moral do seu livre-arbítrio da vontade. A partir dessa compreensão, Agostinho dedicará os seus esforços para construir a sua doutrina a respeito do mal moral, identificando-o como pecado.

Assim, o mal moral passa agora a ser um problema da inadequada utilização do livre-arbítrio da vontade por parte do homem. Diante disso, Agostinho mostra-se convicto de que a

10 - Assevera Agostinho que com vosso livre-arbítrio deveis não fazer o mal, mas praticar o bem, porque esta é a ordenança da lei de Deus nos livros santos do Antigo e Novo Testamentos. (AGOSTINHO, 1956a, p. 251). 
inversão da ordem, representada pela má escolha da vontade, é um pecado contra o Sumo Bem. Desse modo, falar de mal moral e pecado, são tratados como sinônimos no pensamento agostiniano. Doravante, "o problema depende da metafísica, pois a vontade humana é apenas um fragmento da ordem universal" (GILSON, 207, p. 271).

0 pecado, para Agostinho, não tem causa em Deus, mas no homem. Portanto, reitere-se que o problema do mal moral se encontra cravado no comportamento do homem e não no de Deus. "E esse movimento, isto é, o ato de vontade de afastar-se de Deus, seu Senhor, constitui, sem dúvida, pecado. Poderemos, porém, designar Deus autor do pecado? Não! E assim, esse movimento não vem de Deus" (AGOSTINHO, 1995, p. 142).

Agostinho rejeita por completo a hipótese de ser Deus responsável pelo mal moral e, com toda a sua força intelectual, atribui esta falta ao homem. Neste sentido, assinala que o pecado do primeiro homem decorreu do mau uso de seu livre-arbitrio da vontade (AGOSTINHO, 2002a, p. 68).

Em um plano estritamente moral, entende Agostinho que "não há nenhuma outra realidade que torne a mente cúmplice da paixão a não ser a própria vontade e o livre-arbítrio" (AGOSTINHO, 1995, p. 52). De modo mais enfático, afirma o hiponense que "o mal moral tem sua origem no livre-arbitrio da vontade" (AGOSTINHO, 1995, p. 69; 2002a). ${ }^{11}$

Tem-se, portanto, que o livre-arbítrio da vontade é a causa do mal moral, o que vale dizer que o homem é quem, voluntariamente, escolhe subverter a ordem hierárquica dos bens estabelecida pelo Bem incorruptivel e Criador de todas as coisas.

\section{O REMÉDIO EFICAZ PARA O LIVRE-ARBÍTRIO DA VONTADE}

0 livre-arbitrio da vontade foi objeto de acaloradas discussões de Agostinho com os maniqueístas, oportunidade em que se construiu a máxima agostiniana de que não há de se falar na existência ontológica do mal a duelar, em igualdade de poder, com o bem.

Defende Agostinho que Deus fez todas as coisas e todas elas apresentam uma natureza boa pelo fato de serem objeto da criação divina. Ainda, em sua disputa com os maniqueus, sustenta que o movimento de inversão da ordem hierárquica dos bens chama-se pecado, também denominado mal moral, que tem a sua causa na má utilização do livre-arbítrio da vontade (AGOSTINHO, 1995, p. 43 ss.).

Sendo o mal moral um problema centrado exclusivamente na vontade livre do individuo que, por sua vez, voluntariamente escolhe subverter a ordem natural, surge uma questão de

11 - Essa posição é reiterada, por várias vezes, nos escritos de A verdadeira religião, em especial, no capítulo 14 da Segunda Parte da obra (AGOSTINHO. 2002a). 
extrema relevância, qual seja: é possível que o sujeito decaído abandone, sozinho, o movimento de distanciamento do Bem incorruptivel e universal? Ou, em outras palavras: é possível que a pessoa se levante moralmente pelo seu exclusivo esforço sem que, para tanto, haja auxílio externo?

A busca pela resposta da questão a respeito da capacidade ou da incapacidade da criatura humana para salvar-se do mal moral colocou Agostinho em confronto com o pelagianismo, embora ambos sustentassem a possibilidade de o sujeito acertar o alvo em suas escolhas diante da hierarquia de bens. Tanto em um quanto em outro pensador há remédio para o mal moral, sendo que a diferença substancial das posições entre Agostinho e Pelágio centra-se na seguinte indagação: o ser humano possui ou não forças próprias para salvar-se do mal moral e de suas consequências? As refutações de Agostinho a Pelágio ocorreram com o objetivo de defender a sua visão acerca da depravação humana após o pecado original.

Sustenta o pelagianismo que o homem, por sua própria vontade, pode rejeitar o mal e fazer o bem, pelos seus próprios méritos. Para Pelágio a humanidade não herdou o pecado original, visto que a natureza humana é ontologicamente boa (AGOSTINHO, 1995, p. 266). Essas premissas vão de encontro aos dogmas do cristianismo ocidental, em especial aos do catolicismo, que Agostinho tanto se colocou como defensor.

Em seus escritos denominados antipelagianos, Agostinho rebate o pelagianismo e assevera que o homem é herdeiro do pecado original e, por esta causa, corrompeu os seus atos decorrentes da vontade livre. Argumenta, ainda, que o homem decaído nada de bom pode fazer sem a ajuda de Deus que, por meio de sua graça, possibilita que o homem faça o bem que, sozinho, não pode fazer. Neste sentido, a princípio afirmou Agostinho que a vitória sobre o pecado é dom de Deus que ajuda o livre-arbitrio (AGOSTINHO, 1956a, p. 252).

Acentua Agostinho que "a criatura, em si mesma, é boa, porém mutável, e se deteriorou por sua vontade; por esta razão se degradou sua natureza e corrompeu e se fez escrava, não de uma substância estranha, mas de seu próprio pecado" (AGOSTINHO, 1985, p. 105). De onde sucede que "é verdade que o homem que cai por si mesmo não pode igualmente se reerguer por si mesmo, tão espontaneamente" (AGOSTINHO, 1956a).

No tratado Sobre a graça e o livre-arbitrio, Agostinho afirma que a graça de Deus é sempre boa e faz com que a criatura racional tenha boa vontade, sendo que é a atuação divina que permite que a vontade livre tenha força para cumprir os preceitos divinos. Diante da compreensão agostiniana da depravação total do gênero humano desde o momento histórico da queda, o indivíduo não recebe o auxílio da graça por ser ele fiel, mas recebe esse suporte divino para ser fiel aos desígnios ordenados pelo Bem imutável (AGOSTINHO, 1956a).

Em consequência, a visão agostiniana a respeito da pessoa humana é ao mesmo tempo pessimista e otimista. É pessimista quando o foco está na possibilidade humana, visto que este, pelas suas próprias forças da vontade livre não pode fazer o bem. Contudo, o pensamento de Agostinho mostra-se otimista na medida em que o Bem imutável e universal, Deus, 
fortalece o livre-arbítrio da vontade e o fortalece para o alcance do propósito, antes débil, de fazer o bem.

\title{
CONCLUSÃO
}

Em sede de conclusão deste artigo, vale inicialmente registrar que, para Agostinho de Hipona, a criatura racional, embora decaída moralmente desde o episódio do Éden, é plenamente responsável pelos seus atos que culminam no distanciamento do Sumo Bem, imutável e universal. Assim, o Criador não transformou a criatura humana em um fantoche destituído de vontade própria. Em que pese a queda, o sujeito está no controle de suas decisões morais e, por conta disso, tem ele vontade livre, podendo fazer suas escolhas voluntárias por meio do livre-arbítrio que é um bem por natureza. Estas premissas foram defendidas por Agostinho tanto em seus confrontos com os maniqueus quanto em suas controvérsias com os pelagianos, pois ambos os segmentos doutrinários foram fartamente atacados pelo doutor de Hipona quando de sua análise do problema do livre-arbítrio da vontade.

0 fato de o indivíduo ser dotado de vontade livre, capaz de fazer escolhas pelo livre-arbítrio, não quer dizer necessariamente que ele conheça a plenitude da liberdade e da felicidade, eis que para Agostinho o homem somente encontrará a liberdade e a felicidade verdadeiras por meio da aproximação do Sumo Bem, por ele entendido como Deus, o Criador de todas as coisas boas por natureza.

Agostinho esforçou-se, em vários de seus escritos, em demonstrar que o antídoto para o bom homem decaído é a razão, que se manifesta pelo livre-arbítrio da vontade, e a fé, concedido à criatura racional por meio da graça divina.

Desse modo, o Sumo Bem, por meio de sua graça, fortalece a vontade livre do ser humano permitindo a aproximação da criatura com o seu Criador.

\section{The free will of Augustine of Hippo: the dilemma of free will and the moral responsibility of the human being}

\begin{abstract}
The present work aims to analyze the doctrine of Augustine of Hippo in relation to the theme of free will of the will, a problem that was much discussed by the referred author, specifically in his apologetic and polemic works. The problem of evil became a constant concern in Augustine's life and made him a voracious philosopher when he tried to demonstrate that the will finds a preponderant role in understanding the concept of free will, thus showing that this is an intrinsic element make yourself comfortable. Since the free will of the will is the cause by which man practices moral evil, we reserve space to discuss the responsibilities of both man and God for the misuse of this human faculty. It is intended, therefore, to show how the author seeks to exempt God from
\end{abstract}


the accusation of being the author of evil, showing that the cause of the presence of evil in the world derives from the abuse of free will, since, considered in itself, this attribute of the will is a good and a gift from the Creator granted to man himself.

Keywords: Freedom. Will. Bad. Moral. God.

\section{REFERÊNCIAS}

AGOSTINHO. De la gracia y del libre albedrio. In: OBRAS DE SAN AGUSTÍN EN EDICIÓN BILINGÜE. Tomo VI. Traduccion Gerardo Enrique de Veja. Madrid: BAC, Editorial Católica, 1956a. p. 223-301.

AGOSTINHO. Del orden. In: In: OBRAS DE SAN AGUSTÍN EN EDICIÓN BILINGÜE. Tomo I. Traduccion de R. P. Victorino Capanaga. Madrid: BAC, Editorial Católica, 1956b. p. 673-812.

AGOSTINHO. Del génesis contra los Maniqueus. In: OBRAS DE SAN AGUSTín EN EDICIÓN BILINGÜE. Tomo XV. Traduccion Balbino Martín. Madrid: BAC, Editorial Católica, 1957. p. 351498.

AgOStinHO. Confissões. Tradução J. Oliveira Santos, S. J.; A. Ambrósio de Pina, S. J. São Paulo: Editora Abril, 1973. (Coleção os Pensadores, v. VI).

AGOSTINHO. Réplica a Juliano (obra inacabada). In: OBRAS DE SAN AGUSTíN EN EDICIÓN BILINGÜE. Tomo XXXVI. Traduccion R. P. Victorino Capanaga. Madrid: BAC, Editorial Católica, 1985.

AgOSTINHO. O livre-arbitrio. Tradução Nair de Assis Oliveira. São Paulo: Paulus, 1995.

AGOSTINHO. Sobre a potencialidade da alma. Rio de Janeiro: Vozes, 1997.

AGOSTINHO. Dos bens da viuvez: cartas a Proba e Juliana. Tradução Nair de Assis Oliveira. São Paulo: Paulus, 2000a.

AGOSTINHO. Dos bens do matrimônio. Tradução Vicente Rabanal. São Paulo: Paulus, $2000 b$.

AGOSTINHO. A verdadeira religião. 0 cuidado devido aos mortos. Tradução Nair Assis de Oliveira. São Paulo: Paulus, 2002a.

AGOSTINHO. Trindade. Tradução Nair de Assis Oliveira. São Paulo: Paulus, $2002 b$.

AGOSTINHO. A cidade de Deus: contra os pagãos. Parte II. Tradução Oscar Paes Leme. Bragança Paulista: Editora Universitária São Francisco, 2003.

AgOSTINHO. A natureza do bem. Tradução Carlos Ancêde Nougué. Rio de Janeiro: Sétimo Selo, 2005. 
BUSSOLA, C. Plotino: a alma no tempo. Espírito Santo: Fundação Ceciliano Abel de Almeida (FCAA), 1990.

COSTA, M. R. N. Maniqueísmo: história, filosofia e religião. Petrópolis: Vozes, 2003.

CUNHA, M. Palozzi S. da. O movimento da alma: a invenção por Agostinho do conceito de vontade. Porto Alegre: EdiPUCRS, 2001.

EVANS, G. R. Agostinho sobre o mal. Tradução João Rezende Costa. São Paulo: Paulus, 1995.

FRANCA, L. de. Noções de história da philosophia. Rio de Janeiro: Pimenta de Mello e Cia., 1928.

GILSON, É. Introdução ao estudo de Santo Agostinho. Tradução Cristiane Negreiros Abbud Ayoub. São Paulo: Discurso Editorial: Paulus, 2007.

GONZÁLEZ, J. L. Dicionário ilustrado dos intérpretes da fé. Tradução Reginaldo Gomes de Araújo. Santo André: Editora Academia Cristã, 2005. p. 446.

SANTOS, M. F. dos. Convite à Filosofia e à História da Filosofia. 5. ed. São Paulo: Livraria e Editora Logos, [19--]. 